\title{
Engaging Generation Z: A Case Study on Motivating the Post-Millennial Traditional College Student in the Classroom
}

\author{
Kimberlee R. Mendoza \\ San Diego Christian College, California, United States
}

\begin{abstract}
Engagement among the Post-Millennial college student has become problematic due to a culture of technology and instant gratification. Research indicates that student engagement is linked to student learning, and therefore it is essential that professors find improved techniques to reconnect with today's student. Based on Generational Theory, which states that cohorts of people within a certain span of time share certain traits, it is determined that Generation Z (those born between 1995 and 2010) is unlike any other generation before them. The purpose of this research study was to learn what would engage and disengage Generation Z students in the classroom. A single case qualitative case study including journals, interviews, field notes, audiotapes, a personal reflection, and classroom observation were applied. The findings from this study show that relationship, passion, active teaching, and applied learning are all ways in which a professor may be able to connect and engage with his or her class.
\end{abstract}

Keywords: student engagement, Generation Z, higher education, Post-Millennial, active teaching, applied learning

\section{Introduction}

Student engagement is directly linked to learning (Pletka, 2007). There is an emergent challenge to engaging the Post-Millennial generation (Seemiller \& Grace, 2016). Skinner and Belmont (1993) at the American Psychological Association and the National Research Council (2004) identified student engagement as motivation. At a basic level, motivation involves wanting to do something (Petri \& Govern, 2013). It is often seen as a tangible behavior; however, motivation is not always overt. Motivation is complex and varied, making it difficult to measure (Petri \& Govern, 2013). Engagement often can be determined through observable behaviors, such as entering the discussion, writing notes, facial expressions, etc. (Anderman, Andrzejewski, \& Allen, 2011).

Engagement is not a new problem for instructors, but the role of technology has added a fresh challenge (Trowler, 2010). Generation $\mathrm{Z}$ is the first generation to start school with convergence and the existence of modern technology (McCrindle, 2014; O’Connor, 2016). The 21st century traditional college student processes information fundamentally different than their predecessors (Pandit, 2015; Seemiller \& Grace, 2016). Unlike those before them, they acquire knowledge that earlier generations did not confront until much later in life in part due to the fact that two-thirds of Generation $\mathrm{Z}$ were already operating computers before the age of five years (O’Connor, 2016; Pandit, 2015; Seemiller \& Grace, 2016; Zemke, Raines, \& Filipczak, 2013). This interaction with technology while their brains were still developing rewired how they cognize and intercept

Kimberlee R. Mendoza, Ph.D. in Leadership Studies, Director of Instruction \& Services, Non-traditional \& Graduate Studies, San Diego Christian College, California, United States. 
data (Carr, 2010; Richtel, 2010). This is in effect a vital reason for distraction and the failure to concentrate when necessary (Carr, 2010). The most current research indicates that young people are only able to concentrate for eight seconds (Armstrong, 2017; McSpadden, 2015; Seemiller \& Grace, 2016; Vidyarthi, 2011).

Rich (2012) and Carr (2010) both stated that due to the overuse of being on the Internet, a person's brain is not rewarded for remaining in one place but for task skipping to a subsequent site. Though Post-Millennials have an aspiration to ascertain knowledge, the trouble stems from desiring information rapidly and with little effort (O’Connor, 2016).

This intrinsic case study endeavored to establish what instructional practices may engage Generation $\mathrm{Z}$ to be more motivated within the traditional classroom setting. Though research about Generation Z is still new, experts are seeking to understand and connect with this demographic raised with technology (Schwarz \& Zhu, 2015). Understanding the culture of Generation $Z$ could be significant to revealing some best practices for engagement that will affect student learning (M. Johnson \& L. Johnson, 2010).

\section{Literature Review}

The supposition of this study was based on Generation Theory. Generational Theory presupposes that people born within a specific span of time share numerous traits (Strauss \& Howe, 1991). The Generation Z (or Post-Millennials) cohort are made up of persons who were born between 1995 and 2010, which share attitudes, beliefs, behaviors, and social norms dissimilar to other generational cohorts (Seemiller \& Grace, 2016). Post-Millennials will be the main cohort in the traditional college classroom until the year 2032 (Seemiller \& Grace, 2016). Realizing their idiosyncrasies may assist professors with imparting a more effective delivery method of instruction that will hopefully lead to student engagement (Seemiller \& Grace, 2016).

\section{Problem Statement}

Research indicates that most of Generation $\mathrm{Z}$ are intelligent, tech savvy, innovative, driven, and caring but also entitled and lack of a respect for authority (Brotheim, 2014; Seemiller \& Grace, 2016). The Post-Millennials aspire for change and desire knowledge but want any resolution or information to be dispensed quickly (Brotheim, 2014; Pandit, 2015; Seemiller \& Grace, 2016). They have no patience for slow processes and are willing to learn only if it will take little time and effort (O’Connor, 2016; Pandit, 2015; Seemiller \& Grace, 2016). These impediments are key factors for producing fleeting attention spans.

A Post-Millennial student spends each day acquiring data from their laptops and phones, such as weather reports, product information, entertainment news, and instruction (Seemiller \& Grace, 2016). They are trained to check social media updates, instantaneous texts, and other entertaining feeds for pertinent information. They are accustomed to what is called "do not buy options" (Prensky, 2005, p. 2), when certain companies or objects, like a video game, do not deliver on its promise, they can walk away without purchase. These higher expectations have generated some difficulties for present educators (McCrindle, 2014). Discovering systems amidst the technology and distractions is essential for learning. Generation Z's lack of ability to focus, feelings of inadequacy, the distraction of technology, and their view of a purposeless education are all contributors to this disengagement (Seemiller \& Grace, 2016).

Unfocused. If students deem the taught content as futile, they will often become disengaged as well as doubt their own potential (Pletka, 2007). 
Insecure. Much of Generation Z's identity is based on what others think about them, and if they feel they do not understand, they are likely to tune out rather than embarrass themselves with the wrong answer (Pandit, 2015).

Impatient. Communication among most young adults today is immediate and is user driven (Brown, 2011). Post-Millennials often attempt to multi-task. Carr (2010) indicated that multi-tasking hinders the ability to think with intuition, reflection, introspection, and comprehension. The Post-Millennial often desire an instant source of information, such as watching video, rather than spending time reading (Pletka, 2007).

Technological. Technology is not something Post-Millennials do; it is a part of their identity. Elmore (2016) stated, they are "used to commenting, liking, uploading, and upvoting" and engaging with the content online and on their phones (par. 4). According to Pandit (2015), students know they can access information on the Internet at any point, so they see little reason to pay attention, memorize formulas, or learn content written on a white board.

Students may be more engaged and passionate about the material if content is associated with their personal lives and interests, if they are actively involved in the process, if they are able to work collaboratively, and if attention is tied to accomplishing more than just earning a grade (Pletka, 2007).

\section{Methodology}

This study employed a qualitative intrinsic case study to recognize triggers for disengagement among Post-Millennial college students and to discover best practices for facilitating better engagement. The researcher conducted personal interviews, as they related to learning, while also analyzing students' patterns of engagement and disengagement through classroom observation. To study engagement and disengagement, the researcher selected the qualitative method. The researcher used student journals, interview questions, field notes, digitally recorded audiotapes, a personal reflection journal, and classroom observation to aid in the research. Qualitative analysis of the collected data was examined for differences and similarities between participant's answers and coding and categorizing of common themes (Lunenburg \& Irby, 2008). The researcher reached triangulation of the qualitative data through the following three means: personal interviews, observation, and field notes.

\section{Findings}

The researcher used student journals, interview questions, field notes, digitally recorded audiotapes, and classroom observation to aid in the research of the question: What causes Post-Millennial students to become disengaged in the classroom, and how can professors help them become more engaged? In this study, participants were asked only to discuss general education courses, rather than major courses, in an effort to understand engagement in courses in which students may not be as interested. Students were given a list of modalities and asked which ones they felt helped them learn best. Most students listed three or more, desiring an assortment of ways to grasp the content that was presented by the professor. 


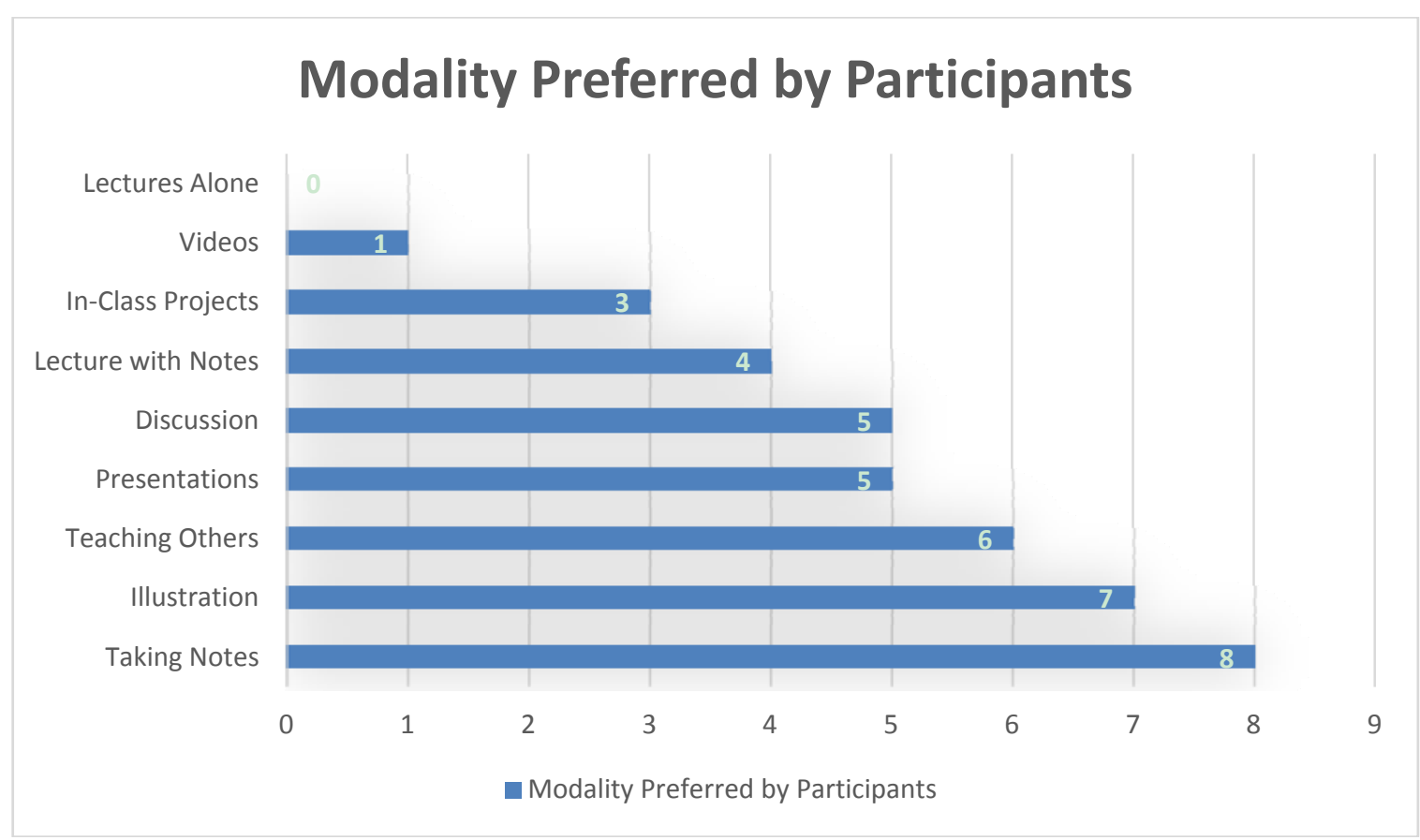

Figure 1. Modalities of instruction preferred by participants.

\section{Summary of the Study}

Student engagement was assessed through observable behaviors, such as openly participating in the class discussion, writing notes, asking questions, facial expressions, eye contact, and posture. Student disengagement was also determined by observable behaviors, such as sidebar conversations, web activity not related to the class, and body language (such as head down or sleeping).

Students who seemed disengaged appeared to reengage whenever a professor changed from lecture to stories, wrote on the board, asked a question, conducted an illustration, or implemented a class activity. Classes with the highest disengagement occurred when professors themselves were not engaging with their students. These professors often remained at a podium while they lectured. It should be noted that in each of these classes, there are few participated and some students slept, clicked into extraneous websites, or participated in sidebar conversations.

The majority of observed students were not using their laptops for notes but were rather surfing the web or engaging with social media platforms. However, students who were given hand notes from their professors appeared to be the most engaged with the material throughout the lecture. This corresponds to the interviews, where $66 \%$ of the students indicated they learned better with the implementation of notes.

When asked questions in the class, students participated more when the answers were not definitive but rather open-ended. Participants in the interviews explained this, stating they fear getting an answer wrong and, therefore will refrain from trying. In all the interviews, it appeared that peer opinion was high coveted and that they would not do anything that might thwart that opinion.

Passionate teaching seemed to be another initiator of engagement. Students' body language suggested that they preferred professors who were energetic and enthusiastic about their topic. Professors who lectured with passion and maintained eye contact with each student appeared to maintain the students' attention $80 \%$ more than those who did not. One observation regarding this phenomenon was that passionate teachers often used 
stories and illustrations to enhance their lectures, which appeared to grasp the students' interest.

Another principal key to student engagement was the relevancy of topic being taught. The researcher assumed relevancy meant for their future, but that did not appear to be the case. Each student interviewed stated that he or she desired information that would be relevant immediately. This lends itself to the literature finding that students are not waiting for a future but desire to live in the moment. As one student pointed out in a finance class, "Do not teach us how to get out of debt, teach us how to stay out of debt".

In summary, from the discussions of these observations with the various participants, it appears that the students desire a passionate teacher, who employs opinion-based questions, implements activities, encourages handwritten notes, shares stories, utilizes illustrations, and applies the content to their current state of living.

\section{Discussion and Conclusion}

The purpose of this intrinsic qualitative case study was to learn why Generation Z students become engaged or disengaged in the traditional four-year college classroom. The overarching theoretical construct for this study was based on generational and motivational theories as well as active teaching and applied learning models as they pertain to Generation Z.

The need for active teaching, however, was a major conclusion found in the literature. Kuh, Kinzie, Schuh, and Whitt (2010), Chickering and Gamson (1999), Hainline, Gaines, Feather, Padilla, and Terry (2010), Heng (2014), and Prensky (2005) argued that education must be more active. This study supports the claims of these researchers. During the observations, students who were completely disengaged became more engaged when discussions or activities were initiated. Generation Z likes to be part of the process (Lieberg, 2008; Seemiller \& Grace, 2016) but only if discussions are open-ended.

\section{What Factors Contribute to Engagement Versus Disengagement?}

Generation $\mathrm{Z}$ has selective attention and disengages if they deem anything less important than another task (Curwood, 2017). Most students in this study knew they were easily distracted and required active and applied learning, such as activities, discussion, storytelling, notes, or illustration. Professors who delivered their lectures dispassionately and were monotone, or who simply focused on assignments more than learning, furthered disengagement.

\section{From a Student Perspective, What Would Best Help Students Stay Engaged?}

Motivation is about arousing a student's curiosity so that he or she can apply it to his or her life (Nilson, 2016). In the student interviews, motivation was ascribed to fun classes and projects. Participants aspired to learn more when they were part of the process. Students also desired some input into their assignments. Choosing their own topics seemed valuable to the participants.

Another characteristic that came out in the interviews was that if the professor displayed concern for their well-being, students were more likely to enjoy the class. This in part could be due to the developed relationship and the student not wanting to let the professor down (Kuh et al., 2010).

\section{How Can Higher Education Professors Effectively Engage Generation Z in the Classroom?}

The literature argued that active or applied learning would be the best way to engage students in the classroom (Kuh et al., 2010; Seemiller \& Grace, 2016). The research collected in this study agreed with this assessment. Students liked the open discussions and did not care about topics that did not seem relevant to their immediate future. 
Ninety-two percent identified with being kinesthetic and wanted to be doing something. Covey (2005) was quoted in the research as saying, "To know and not to do, is really not to know" (p. 33). This generation is accustomed to being hands-on. They desire to be part of the process.

\section{Why Do Students Become Disengaged in the Classroom?}

The researcher inquired if professor personality, delivery, relevance, or something else was the reason for disengagement. Personality was an immense component in the interest of the students. More outgoing professors, who were naturally enthusiastic, seemed to hold student attention longer. One thing to consider within generational theory is that each generation has a distinct personality (McCrindle, 2014; Strauss \& Howe, 1991; Zemke et al., 2013). This could affect how students perceive a certain professor.

Relevance was also deemed important, but overall the students cared about the actual delivery-the passion, the fun, and open discussions. Participants appeared to disengage when professors were merely lecturing but did engage when stories were told. This was a constant in the literature. Lecture is teacher-centered with a one-way flow of information, but today's student wants to be involved and share their opinions (Money, 2014; White, 2013).

\section{What Are the Personality Characteristics of Generation $\mathrm{Z}$ as a Cohort and What Do They Want From Their Education?}

Some of the definitions that were used in the research to define this generation were driven, optimistic, diverse, impatient, and flexible (Brotheim, 2014; O’Connor, 2016; Seemiller \& Grace, 2016). Generation Z was said to have short attention spans with a strong need for instant gratification (McCrindle, 2014; Stuckey, 2016). These character traits were evident in the observations and the interviews. They are dreamers who desire to do more now. They are impatient, not intending to wait for a desired future. They are not focused on the imminent but the immediate. They long to learn but only when it is rapid and relevant.

Also, there was a formidable appeal to be heard, and students disliked being told what to think. As the research and the study show, Generation $\mathrm{Z}$ suffers from inferiority and needs encouragement. They are quick to stay quiet if they feel that their answers will be deemed wrong. This supports the National Survey of Student Engagement (NSSE) data that stated students need positive attitudes to be more engaged (Korobova \& Starobin, 2015).

Students also want real and authentic teachers. They like when a professor is humanized through stories (Lordly, 2007). Stories have shown to build relationships and intimacy with their professors (Kuh et al., 2010). It is also important to note that when professors were lecturing, students' heads were down, but when he or she switched to a story, heads lifted, computers shut off, and for a moment, students seemed to reengage.

An unanimous desire was that students crave fun. At some level, they want to be entertained with new ideas and concepts that are fresh and presented in a unique way. This was also noted in the research. Milner (2011) stated that Generation Z wants tasks that will help them to learn in a fun way. One article stated that fun could be introduced into the classes using games, social media, and forums (Jambulingam, Selvarajah, \& Thuraisingam, 2014).

Participants in this study liked classes that appealed to their personal interests. Student liked when professors gave them a choice within these creative ideas. One participant mentioned that normally she hates research, but when she is given the opportunity to choose her own topic, she loved the process. 


\section{How Important Is Technology to the Current College Student and His or Her Engagement?}

When students were using their laptops and cell phones in all the observed classes, they were disengaged. Most students used the time to complete other homework or to surf the web. Only a few actually used their computers for notes. One participant mentioned not liking his cell phone taken away but stated that if he were on it he would definitely be disengaged. When students were asked about the use of technology in the class, all of them responded that laptops and cell phones were a distraction.

Davidson and Goldberg (2010) suggested that universities need to incorporate technology into their learning, which raises another question: If the students believe these devices are a distraction, how do professors use them in a way that can help rather than hinder student learning? This question was not answered in the research and affords itself to another study. It should also be noted that the participants in this study did not like online discussion forums and would prefer face-to-face time with the professor.

\section{Implications of the Research Study}

The purpose of this research study was to learn what would engage and disengage Generation $\mathrm{Z}$ students in the classroom. The study was also intended to help professors from other generations understand what teaching methods may be more successful for the 21st century college student.

Administrators. When hiring faculty, administrators may want to assess the candidate's passion for his or her field. Administrators may also want to observe faculty and coach lecture only professors. Also, administrators may consider student satisfaction surveys that include the numerous suggestions considered in this research. Though it was not directly discussed in the research, retention is a factor the administration may want to consider. From this study, the researcher has concluded that if students have a good product (i.e., their classroom experience), they are more likely to enjoy their classes and stay engaged—not only in academics but also in the college. According to Hess (2018), the college completion rate is now $28 \%$ and that nearly 2 million students drop out of college every year. Students need to see the value of the education they are paying for (Hess, 2018).

Faculty. Faculty may reflect on their own teaching styles and decide if they are still passionate about their subject matter. They might want to consider altering their syllabi to include innovative objectives that entail contemporary situations and pop culture that may be relevant to students today.

Lessons need to be active for students to stay focused. Professors may also want to consider sharing stories, as it was demonstrated that stories often helped reengage students as well as make the professor seem more authentic. Also, though some faculty may be opposed to the notion of fun in the classroom, this generation flourishes in that milieu.

Additionally, it is essential that faculty engage with the students, too. Several of the observed classes had sleeping students, students on laptops/cell phones, and sidebar conversations. If a faculty member were to engage with those students, each of the students would be more likely to stay alert.

And lastly, faculty need to be positive and encouraging, urging students to communicate their own opinions. Encouragement and engagement are responsible for academic success (Evans, 1997; Kuh et al., 2010). This study demonstrated that the more professors can help students see their value, the more value students will place on their education.

\section{Areas for Further Research}

Although this case study provided meaningful information, additional research at other institutions would 
be beneficial for higher education. Understanding this generation is much broader than the researcher could do at one small and non-profit institution. Conducting a study at larger schools, would likely give a better appreciation of what causes students of this generation to become engaged.

One of the biggest questions in this study was determining if the characteristics of the professor has more to do with engagement than the actual delivery method. This was not clearly answered. Contrary to the literature, students were engaged in one class when lecture was the sole basis of the professor's delivery method because the professor was passionate and told multiple stories. However, in another class, when that professor was clearly passionate and asked discussion questions, students were not fully engaged. More research could be conducted to possibly compare and contrast these two teaching styles to further answer what students truly desire in a professor and the classroom. The research could also expand to lecture-halls and large classes to determine if some of these techniques would work in a larger setting.

The research was also limited to a qualitative study. Conducting a quantitative study, at various institutions, could give further data to the needs and wants of this generation. Administering a survey to a large number of students could also be beneficial for collecting data.

The study also did not account for online or hybrid learning. Conducting a research study on the engagement and disengagement of those who have limited interaction with the professor and classmates could be beneficial.

This study was focused on general education classes only. It would also be important to find out if engagement does indeed increase in major courses or if it is still dependent on the teacher's passion. Research could be conducted on students who are in core classes to determine if there is any difference in the level of engagement when topics are attached to a major.

\section{Summary}

The purpose of this study was to learn why Post-Millennial students (those born between 1995 and 2010) become engaged or disengaged in the traditional four-year college classroom, which was done through observation and personal interviews. Due to the multiple distractions and the kinesthetic nature of this generation, lecture by itself is no longer the most efficient way to approach teaching. Active teaching and applied learning are needed to fully engage this cohort. In order for students to learn, they must be engaged, and therefore it is important for faculty to work to achieve this through passion, hands-on activities, open discussions, and innovative ideas. The delivery method of instruction has been shown to be a huge component to student learning. Both the research and this study demonstrate that using active and applied techniques will help improve student engagement, which will in turn better equip the next generation for the future.

\section{References}

Anderman, L., Andrzejewski, C. E., \& Allen, J., (2011). How do teachers support students' motivation and learning in the classroom? Teachers College Record, 13(5), 969-1003.

Armstrong, T. (2017). The myth of the ADHD child: 101 ways to improve your child's behavior and attention span without drugs, labels, or coercion. New York, NY: Tarcher Perigee.

Baskarada, S. (2013). Qualitative case study guidelines. Victoria, Australia: Joint and Operations Analysis Division Commonwealth of Australia. Retrieved from http://www.dtic.mil/get-tr-doc/pdf?AD=ADA594462

Bembenutty, H. (2009). Academic delay of gratification, self-regulation of learning, gender differences, and expectancy-value. Personality and Individual Differences, 46(3), 347-352. 
Brown, J. S. (2011). Innovation expert John Seely Brown on new ways of learning in a rapidly-changing world. Retrieved from https://www.youtube.com/watch?v=bGdpbba1i9c

Brotheim, H. (2014). Introducing Generation Z. American Jails, 28(5), 15-16, 19-20. Retrieved from http://connection.ebscohost.com/c/articles/99979241/introducing-generation-z

Carr, N. (2010). The shallows: What the internet is doing to our brains. New York, NY: W. W. Norton Company.

Chickering, A. W., \& Gamson, Z. F. (1999). Development and adaptations of the seven principles for good practice in undergraduate education. New Directions for Teaching and Learning, 80, 75-81. Retrieved from https://doi.org/10.1002/tl.8006

Covey, S. R. (2005). The 8th habit: From effectiveness to greatness. New York, NY: Free Press, Simon \& Schuster.

Creswell, J. (1998). Qualitative inquiry and research design: Choosing among five traditions. Thousand Oaks, CA: Sage Publications.

Curwood, J. S. (2017). Wired up: Tuned out. Scholastic News. Retrieved from http://www.scholastic.com/browse/article.jsp?id=3752302

Davidson, C. N., \& Goldberg, D. T. (2010). The future of thinking: Learning institutions in a digital age. Cambridge, MA: MIT Press. Retrieved from https://dmlhub.net/wp-content/uploads/files/Future_of_Thinking.pdf

Elmore, T. (2016). Homelanders: The next generation. Influence Magazine. Retrieved from https://influencemagazine.com/practice/homelanders-the-next-generation

Evans, T. D. (1997). The tools of encouragement. Reaching Today's Youth, 1(2), 10-15. Retrieved from https://gal2.org/library/documents/volunteer/continuing-education/tools-of-encouragement.pdf

Gentry, J. (1990). The guide to business gaming and experiential learning. Asbury, IA: Nichols Publishing.

Hainline, L., Gaines, M., Feather, C. L., Padilla, E., \& Terry, E. (2010). Changing students, faculty, and institutions in the

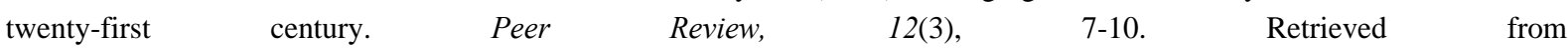
https://www.aacu.org/publications-research/periodicals/changing-students-faculty-and-institutions-twenty-first-century

Hess, F. (2018). The college drop out problem. Forbes. Retrieved from https://www.forbes.com/sites/frederickhess/2018/06/06/the-college-dropout-problem/\#12851b075fd2

Heng, K. (2014). The relationships between student engagement and the academic achievement of first-year university students in Cambodia. The Asia-Pacific Edu Researcher, 23(2), 79-189. Retrieved from https://doi.org/10.1007/s40299-013-0095-8

Jambulingam, M., Selvarajah, C., \& Thuraisingam, A. (2014). Social media networks and Gen Z. Research Journal of Applied Sciences, Engineering and Technology, 8(8). Retrieved from https://doi.org/10.19026/rjaset.8.1067

Johnson, M., \& Johnson, L. (2010). Generations, Inc: From boomers to linksters-managing the friction between generations at work. New York, NY: Amacom.

Johnson, R. B., \& Christensen, L.B. (2017). Educational research: Quantitative, qualitative, and mixed approaches (6th ed.). Los Angeles, CA: Sage Publishing.

Korobova, N., \& Starobin, S.S. (2015). A comparative study of student engagement, satisfaction, and academic success among international and American students. Journal of International Students, 5(1), 72-85. Retrieved from http://files.eric.ed.gov/fulltext/EJ1052833.pdf

Kuh, G. D., Kinzie, J., Schuh, J. H., \& Whitt, E. J. (2010). Student success in college: Creating conditions that matter. San Francisco, CA: Jossey-Bass.

Lieberg, C. S. (2008). Teaching your first college class: A practical guide for new faculty and graduate student instructors. Sterling, VA: Stylus Publishing.

Lindeman, E. (1962). The meaning of adult education. Montreal, Canada: Harvest House, Ltd.

Lordly, D. (2007). Once upon a time...Storytelling to enhance teaching and learning. Canadian Journal of Dietetic Practice and Research, 68(1), 30-35. Retrieved from https://doi.org/10.3148/68.1.2007.30

Lunenburg, F. C., \& Irby, B. J. (2008). Writing a successful thesis or dissertation: Tips and strategies for students in social and behavioral sciences. Thousand Oaks, CA: Corwin

McCrindle, M. (2014). The abc of xyz: Understanding the global generations (3rd ed.). Bella Vista, NSW: McCrindle Research Pty Ltd.

McSpadden, K. (2015). You now have a shorter attention span than a goldfish. TIME. Retrieved from http://time.com/3858309/attention-spans-goldfish/

Milner, H. R. (2011). Five easy ways to connect with students. Harvard Education Letter, 27(1). Retrieved from http://hepg.org/hel-home/issues/27_1/helarticle/five-easy-ways-to-connect-with-students_492 
Moeny, J. (2014). Teaching should be two-way interaction, not student-centered, author says. Retrieved from http://blogs.edweek.org/teachers/teaching_now/2014/11/teaching-two-way-interaction-not-student-centered-rodriguez.html

Nilson, L. (2016). Teaching at its best: A research-based resource for college instructors (4th ed.). San Francisco, CA: Jossey-Bass, A Wiley Imprint.

O’Connor, W. (2016). Generation Z: How this generation is different from Millennials (what parents need to know). Seattle, WA: Amazon Digital Services.

Pandit, V. (2015). We are Generation Z: How identity, attitudes, and perspectives are shaping our future. Dallas, TX: Brown Books Publishing Group.

Petri, H. L., \& Govern, J. M. (2013). Motivation: Theory, research, and application (6th ed.). Boston, MA: Wadsworth Cengage Learning.

Pletka, B. (2007). Educating the Net generation: How to engage students in the 21st century. Santa Monica, CA: Santa Monica Press.

Prensky, M. (2005). “Engage me or enrage me”: What today’s learner demands. EDUCAUSE Review, 40(5), 60-65. Retrieved from https://er.educause.edu/articles/2005/1/engage-me-or-enrage-me-what-todays-learners-demand

Rich, M. (2012). Promise and peril pt 1: The impact of technology on children, schools and communities. Dr. Michael Rich. Retrieved from https://www.youtube.com/watch?v=rfKajz5OXBA

Richtel, C. M. (2010). Growing up digital, wired for distraction. New York Times. Retrieved from http://www.nytimes.com/2010/11/21/technology/21brain.html?pagewanted=all\&_r=0

Savage, S., \& Geck, C. (2006). The Generation Z connection: teaching information literacy to the newest net generation. Teacher Librarian, $\quad 33(3), \quad 19-23 . \quad$ Retrieved from http://www.redorbit.com/news/technology/397034/the_generation_z_connection_teaching_information_literacy_to_the_new est/

Schwarz, C., \& Zhu, Z. (2015). The impact of student expectations in using instructional tools on student engagement: A look through expectation disconfirmation theory lens. Journal of Information Systems Education, 26(1), 47-58.

Seemiller, C., \& Grace, G. (2016). Generation Z goes to college. San Jose, CA: Jossey-Bass.

Skinner, E. A., \& Belmont, M. (1993). Motivation in the classroom: Reciprocal effects of teacher behavior and student engagement across the school year. Journal of Educational Psychology, 85(4), 571-581. Retrieved from https://doi.org/10.1037//0022-0663.85.4.571

Strauss, W., \& Howe, N. (1991). Generations: The history of America's future, 1584 to 2069. New York, NY: Quill William Morrow.

Stuckey, C. (2016). Preparing leaders for Gen Z. Training Journal. Retrieved from https://www.trainingjournal.com/articles/opinion/preparing-leaders-gen-z

Trowler, V. (2010). Student engagement literature review. The higher education academy. Lancaster, UK: Lancaster University. Retrieved from https://www.heacademy.ac.uk/system/files/studentengagementliteraturereview_1.pdf

Vidyarthi, N. (2011). Attention spans have dropped from 12 to 5 minutes-How social media is ruining our minds. Retrieved from

http://www.adweek.com/socialtimes/attention-spans-have-dropped-from-12-minutes-to-5-seconds-how-social-media-is-ruini ng-our-minds-infographic/87484

White, D. D. (2013). Is anybody out there learning anything? Ministry Today. Retrieved from http://ministrytodaymag.com/leadership/preaching/420-is-anybody-out-there-learning-anything

Yin, R. K. (2013). Case study research: Design and methods (5th ed.). Thousand Oaks, CA: Sage Publication.

Zemke, R., Raines, C., \& Filipczak, B. (2013). Generations at work: Managing the clash of veterans, Boomers, Gen Xers, and Gen Yers in the workplace. New York, NY: American Management Association. 